Makale Gönderim Tarihi/Received Date: 23.09.2020 - Makale Kabul Tarihi/Accepted Date: 09.11.2020

Toplum ve Kültür Araştırmaları Dergisi

Journal of Social and Cultural Studies

www.toplumvekultur.com

Y11/Year:2020, Say1/Issue: 6, Sayfa/Page:65-80

DOI: $10.48131 /$ jscs. 798412

\title{
AKADEMİSYENLİK MESLEĞİNDE ETİK KOD ARAYIŞI ${ }^{1}$
}

Günce DEMIR ${ }^{2}$

\section{$\ddot{O} z$}

Etik ve etik kod kavramı son yıllarda sıklıkla karşımıza çıkmaktadır. Ülkemizde bilimsel çalışma etiği ve bilim etiği üzerine birçok çalışma yapılmışken, akademisyenlik mesleğine yönelik hazırlanmış etik kod oluşturma çabalarının sınırlı kaldığı görülmektedir. Geleceğin iş görenlerini ve girişimcilerini iş dünyasına hazırlayacak olan akademisyenlerin davranışları ve tutumlarıyla çevrelerine ve özellikle öğrencilerine örnek olmaları beklenmektedir. Bu nedenle akademisyenlik mesleğinde, etik kodlar ile belli bir standart sağlanması hedeflenmektedir. Akademisyenlik mesleğinde etik kodların geliştirmesi ile akademisyenlerin güvene ve dürüstlüğe dayalı değerler çerçevesinde çalışacağı bir ortam yaratılarak, bu değerlerin yazılı hale getirilmesi ve geliştirilmesi amaçlanmaktadır. Böylece hem yetiştirdikleri öğrencilere örnek olma hem öğrencilerin doğru ve tarafsız bilgiye ulaşmalarını sağlama hem de kendi meslek hayatlarında ahlaki değer ve tutum içerisinde çalışmalarına ortam oluşturma imkânı bulacaklardır. Bu noktadan hareketle çalışmada akademisyenlik mesleğinde etik kodlanın ve önem derecelerinin belirlenmesine yönelik bir araştırma yapılmıştır. Araştırma sırasında yöneltilen sorular belirli başlıklar altında toplanmıştır. Akademisyenlerin öğrencilerine, mesleğe, meslektaşlarına, topluma ve bilime karşı sorumlulukları başlıkların belirlenmesinde etkili olmuştur. Belirlenen başlıkları kapsayan sorular çalışma dahilinde uygulanan anket ile Türkiye'deki çeşitli üniversitelerde görev yapan akademisyenler arasından rastgele seçilen 2288 akademisyene e-mail yolu ile ulaştırılarak görüşleri alınmış ve cevaplar istatistiksel olarak incelenmiştir. Gönderilen anketlerden ancak 172 tanesine kullanılabilir şekilde dönüş alınmıştır. Kullanılabilir durumdaki anketlerden elde edilen veriler doğrultusunda akademisyenlerin öğrencilerine, mesleklerine, meslektaşlarına, topluma ve bilime karşı sorumluluklarına yönelik etik kodlar geliştirilmeye çalışılmıştır.

Anahtar Kelimeler: Etik, etik kod, akademisyenlik mesleği, meslek etiği

\footnotetext{
1 “Akademisyenlik Mesleğne Yönelik Etik Kodların Geliştirilmesine İlişkin Görguil Bir Araştırma” başlıklı yayımlanmamıs yüksek lisans tezinden üretilmiştir.

2 Arş. Gör. Dr., Kırıkkale Üniversitesi Fen Edebiyat Fakültesi Sosyoloji Bölümü, gunceyilmaz@gmail.com, ORCID: 0000-0001-7747-6769
} 


\title{
PURSUIT OF ETHICAL CODE IN ACADEMY
}

\begin{abstract}
The concept of ethics and the ethical code have come up frequently in recent years. In Turkey, there are many studies which had been conducted on "scientific work ethics" and "ethic science". However, it is also seen that the efforts of creating an ethical code for academic profession are limited. Academicians who prepare future's business people and entrepreneurs to the business world, are expected to be a role model with their behaviors and attitudes to the people around them, and especially to their students. For that reason, it is aimed to be providing a certain standard of ethical codes for academic profession. With the development of ethical codes for the profession of academics, the target is to create and develop an environment where academicians will work within the framework of values based on trust and honesty. Therefore, they would have the opportunity to be a role model for the students those they train, to ensure that students have access to correct and impartial information, and to create an environment for their work in their professional lives with moral values and attitudes. With this point of view, a research is conducted to determine the ethical codes and degrees of importance in the profession of academics. The questions posed during the research are grouped under certain headings. The responsibilities of academicians for their students, profession, colleagues, society and science, have been effective while determining the topics. Questions covering the determined topics are sent to 2288 academic staff, who are randomly selected, by an e-mail. Only 172 of the questionnaires are answered properly. After gathering replies, the obtained data is used for ethical codes to be extracted and clarified for the responsibilities of academicians to their students, professions, colleagues, society and science.
\end{abstract}

Keywords: Ethics, Ethical code, academic professions, professional ethics

\section{Giriş}

"Etik" kavramı, yaklaşık 2500 senedir özellikle felsefeciler tarafindan tartışılmakta ve bu süre içinde, neyin iyi ve doğru ya da kötü ve yanlış olduğuna yönelik çeşitli çalışmalarda farklı yaklaşımlara rastlanmaktadır. Ancak etik kavramı tarihsel süreç içerisinde, çoğu zaman ahlak ile eş anlamlı olarak kullanılmıştır. Yüzyıllar boyu yaşamın ahlaki boyutunu da içeren, yani insanın yaşamındaki erdem, fazilet gibi değerlerini ve yargılarını incelemiştir. Preston (1996), Johnson ve Reath (2004) gibi yazarlara göre; ahlak, Latince kökenli "morality" teriminden gelen anlamıla, insanların birbirleriyle veya devletle olan ilişkilerinde kendilerinden yapmaları istenen ve bu nedenle toplum düzeninin sağlanmasında önemli bir rolü olan kurallar ve normlar bütünüdür. Ahlak toplumsal bir olgu olarak, toplumdan topluma ve zaman içerisinde de değişebilmektedir. Bundan dolayı her toplumun kendine göre bir ahlak anlayışı vardır. Etik ise bu farklı ahlakların kesiştiği ortak noktada oluşmakta ve evrensel normları ortaya koymaktadır. Ahlak Latince olmasına karşın etik Yunanca kökenli bir kelimedir ve “prensip", "karakter" anlamına gelen "etikhos "kelimesinden gelmektedir. Ancak etik bu anlamdan farklı olarak dilimizde "ahlak felsefesi” olarak da kullanılmaktadır. Etik sözcüğünün etimolojik kökeni Yunanca ethos kelimesinden gelmektedir. Ethos sözcüğü ise; birbirinden farklı birçok anlama gelmektedir. 
Yunancada çoğul olarak kullanıldığında genellikle bir kişinin esas yeri, yurdu, kaldığ1 yer, ikamet ettiği ev bark, memleket anlamına gelmektedir. Sözcügün genellikle çoğul olarak kullanıldığında karşılaştığımız anlamlar, alışkanlıkları, geçmişten gelen birikimleri, insan davranışının alışıldık, bildik tarzlarını, hayatın belli alışkanlıklarını, töreleri, adetleri vs. kapsamaktadır (Atayman, 2005: s.11)

Bir toplumda çoğunlukla yazılı olmadığı halde, yaygın olarak bilinen ve uygulanmaya çalışılan bazı kurallar mevcuttur. Bu kuralları, genelde etik değerler şekillendirmektedir. $\mathrm{Bu}$ nedenle etiği açıklayan kavramların başında "değer", "inanç” ve "norm” kavramları gelmektedir.

Kuçuradi'ye (2003) göre etik kavramı, çok eski olmakla birlikte özellikle son y1llarda moda olan bir kavramdır. Ancak bununla beraber etik, felsefe disiplinleri içerisinde yeri belirgin olan bir disiplin olmasına karşın, konu ve konuyla ilgili sorunların çeşitliliği nedeniyle teori çokluğu bakımından kavramın netlik kazanamaması sorunu yaşanmaktadır.

Kant'a (2003: s.86) göre ahlak, etik öğretisi şeklinde de tanımlanmaktadır. Çünkü eylemin doğruluğu içseldir. Baskı nedeniyle yasaları uygulayan bir kimse henüz erdemli değildir. Burada erdem; insanın ahlaksal zihniyet bakımından kendine hâkim olma ve kendini aşma gücünü göstermektedir.

Sonuç olarak etik; insanların izlemesi beklenilen ahlak ilkeleri üzerindeki felsefi yaklaşımları içermektedir. Bu yaklaşımlar, hem ahlaki değerler ve nedenselliklerinin ispatı ile ilgili çalışmaları açılayan bir disiplini, hem de yaşanılan davranış ilkelerini ve eylemsel değerleri içine alan disiplinin konularını ifade etmektedir.

\section{Etik Kod Nedir?}

Etik kavramına ve özellikle iş etiği konusunda işletmelerin etik kod geliştirme çalışmalarına, son yıllarda büyük ilgi gösterilmektedir. Bununla birlikte aslında etik ve etik ile ilgili diğer kavramlar, Türkçeye yeni yeni girmeye başlamış ve bu nedenle hem literatürde hem de günlük hayattaki kullanımlarında farklı veya hatalı kullanımlar söz konusu olabilmektedir. Örneğin Tevruz (2007) Akademisyen Harun Tepe’nin 1998 yllında akademik bir dergiye gönderdiği "Etik ve Meta-etik" başlıklı yazısına editörün verdiği cevapta, etik sözcüğü editöre anlamsız göründüğü için kelimenin "etnik" olarak düzeltilmesi istendiğinden bahsetmektedir. Yine TEDMER (Türkiye Etik Değerler Merkezi) tarafından 2002'de yapılan bir araştırmada “iş etiği kavramını duydunuz 
mu?" sorusuna verilen cevapların \%36 sinın "hayır" olması, bu kavramın ülkemizde hala yeterince bilinmediğini göstermektedir. Benzer bir durum, Baumhart'ın 1968'de 100'den fazla iş insanı üzerinde yapmış olduğu bir çalışmada görülmüştür. Araştırmaya katılan iş insanlarına "etik sizin için ne anlamına geliyor?" sorusu yöneltilmiştir. Soruya verilen bazı cevaplar şu şekildedir, "Ne demek olduğunu bilmiyorum.”, "Hislerimin bana doğrudur dediği şeydir.”, “Ahlaki standartlardır.”, “İnsanın kişisel veya sosyal refahı için belirlenmiş standartlardır.”, "Doğru olduğuna inandığımız şeylerdir.” şeklinde olmuştur. Aslında bu cevaplar etik ile ilgili olsa da etiği tanımlamakta yetersiz kalmaktadır (Tevruz; 2007: s.2). Pearson ve Nelson ( 2000 ) kod kavramını, "diğer kişi ya da kişilerin zihninde anlamlar yaratmak için kullanılan simgelerin sistematik olarak düzenlenmiş halidir” şeklinde tanımlarken (Harlak, 2003: s.19), Pater ve Gills (2003: s.764) ise etik kodları; ahlâkî uyum politikalarını içeren yani ahlâkî standartlar, temel değerler, prensipler, organizasyonun etik uyumunu ifade eden ve iş görenlerin davranışlarına veya organizasyonun tümüne rehberlik etmesi amacıyla oluşturulan resmi ve yazılı dokümanlar şeklinde tanımlamaktadırlar.

Merkezi Londra'da bulunan Institute of Business Etbics yaptığı değişik çalışmalara dayanarak, yalnızca etik kodların oluşturulmasının yeterli olmayacağını belirtmektedir. Çalışanların özellikle karşılaşabilecekleri etik; ikilemlere açıklık getirmenin gerekliliğini belirtmektedir. Ayrıca etik kodlar çalışanlara duyurulduktan sonra da izlenmesinin gerekliliğini vurgulamaktadır (Svensson, 2004: s.180). Özetle etik kodların önemine yapılan vurgulamaya karşın "Etik bir koda sahip olmak her zaman tüm sorunları çözer” iddiasında bulunmak da doğru değildir (Russ- Eft ve Hatcher, 2003: s.304). Çünkü etik kodların etkinliğini arttırabilmek için çalışanların ve yöneticilerin bu konuda sürekli olarak bilinçli olması gerekmektedir. Programlı olarak etik konusunda eğitim çalışmaları yapılmalıdır. Ayrıca bu çabaların performans değerlendirmesi yapılarak işletmelerin yön tayin etmesinde etkili faktörler tespit edilmelidir.

\section{Akademisyenlik Mesleğinde Etik Kodların Önemi}

İnsanın olayları anlama merakı, onu daha ilk çăglarda soru sormaya ve yanıt aramaya yöneltmiş ve dolayısıyla bu itici güç bilimin doğmasına ve gelişmesine yol açmıştır. Bazı olay ve olgular karşısında düzenlenmiş bilgiler bütünü, kavramsal olarak bilimin anlam ve özünü oluşturmaktadır. Bilimi yaratan taraf, gözlem ve araştırmaya dayalı değerlendirme sarmalında uğraşan yani "fikri ve bedensel emeğini ortaya koyan 'bilimci'dir" veya başka bir ifadeyle bilim insanıdır. Bilim insanı; Zweig’e göre, evrensel düşünen kişidir, objektiftir, ahlaki sorumluluğu 
yüksek olan kişidir, aydınlanmış kişidir, öngörüsü yüksek olan kişidir. Ancak bilim insanının her şeyden önce kendi çalısma konusunu tam olarak bilmesi, bu alanda bilgi üretmesi gereklidir (Ortaş, 2004: s.1).

Akademisyenlik mesleğinde etik kodların geliştirilmesi alanında çalışmalar incelendiğinde Etik ve etik kod kavramı günümüzde pek çok alanda karşımıza çıkmaktadır. Etik kodlar, davranışları yöneten rehber şeklinde tanımlanabilir ve bu kodlar genel olarak bir kurumun ya da mesleğin çalışma prensiplerine yönelik olarak geliştirilirler. Dünyada ve ülkemizde pek çok meslek için etik kodlar geliştirilmeye ve uygulanmaya başlanmıştır.

Akademisyenlik mesleğinde etik kodlar ile ilgili literatür taraması yaptığımızda ise karşımıza "bilimsel araştırma etiğì" ile ilgili pek çok çalışma ve araştırma çıkmasına rağmen, mesleğin geneline ilişkin herhangi bir çalışmaya rastlanmamaktadır. Oysa akademisyenlerin güvene ve dürüstlüğe dayalı değerler çerçevesinde çalışabilmesi için akademisyenlik mesleğinde etik kodların geliştirilmesinin yararlı olacağı düşünülmektedir. Ayrıca akademik etik kapsamında belli standartlar geliştirilmesi ile üniversite içinde ve üniversiteler arasında sağlıklı bir çalışma ortamının yaratılması hedeflenmektedir.

Akademisyenlik mesleğinde bilimsellik, öğretim, yönetim ve toplumsal sorumluluklarla ilişkili etik değerlerin güçlendirilmesi için çaba göstermek ve etik olmayan davranışlarla mücadele etmek üniversitelerin en önemli görevlerindendir. Etik kodların ortaya konulmasıyla akademisyenler, öğrenciye, meslektaşa, mesleğe, topluma ve bilime karşı sorumluluklarına daha rahat bir şekilde sahip çıkabileceklerdir. Ülkemizde bilimsel çalısma etiği ve bilim etiği üzerine birçok çalışma yapılmışken, akademisyenlik mesleğine yönelik hazırlanmış etik kod oluşturma çabalarının sınırlı kaldığı görülmüştür.

\section{Akademisyenlik Mesleğinde Etik Kod Geliştirilmesi}

Bu çalışma akademisyenlerin güvene ve dürüstlüğe dayalı değerler çerçevesinde çalışacağ1 bir ortam yaratılarak, bu değerlerin yazılı hale getirilmesi ve geliştirilmesi amacıyla bir ön çalışma niteliği taşımaktadır. Çalışmanın genel yapısına değinildiğinde; ülkemizdeki üniversitelerde fiili olarak görev yapan akademisyenlerin görüşlerinden yola çıkılarak, akademik alandaki herkes tarafindan kabul edilebilecek mesleki etik kodların belirlenmesi amaçlanmaktadır. Bu amaçla akademisyenlik mesleğiyle ilgili literatür taranarak bir kod listesi oluşturulmuştur. Oluşturulan bu 
kod listesi değişik üniversitelerde görevli ve konuyla ilgili çalışmaları bulunan akademisyenlere gönderilerek görüşleri alınmış ve neticede 71 sorudan oluşan bir kod listesi belirlenmiştir. Oluşturulan bu etik kodlar listesi daha sonra değişik üniversitelerin değişik fakültelerinde görev yapan akademisyenlere gönderilmiş ve bu ilkelerle ilgili görüşlerini 0-5 arasında verecekleri puanlarla belirtmeleri istenmiştir. Söz konusu bilgiler elektronik ortamda anket tekniğiyle elde edilmiştir Araştırmaya konu olan ana kitlenin büyüklüğü ve tamamına ulaşma zorluğu nedeniyle rastlantısal olarak, ana kitlenin özelliklerini yansıtan ve daha az sayıda elemandan oluşan bir örneklem grubu oluşturulmuştur. İnternette üniversitelerin resmi sitelerinde yer alan, akademisyenlere ait elektronik posta adreslerinden, ana kitleyi temsil etmek için rastgele seçilen 2288 akademisyene gönderilen ankete ancak 205 akademisyenden cevap alınabilmiştir. Anketin uygulandığ1 2006-2007 yıllarında internetin günümüzdeki kadar yaygın kullanılmaması ve e-mail ile haberleşmenin yeni yeni hayatımıza dahil olduğu bir dönemde, e-mail yolu ile anket uygulaması gibi yeni bir yaklaşım ile araştırmanın kurgulanması ankete katılım oranının düşük olmasına sebep olmuştur. Ayrıca geri dönüş alınan ve incelenen 205 anketten 172 tanesinin araştırmada kullanılabileceği anlaşılmıştır. Kullanılamayan 33 ankettin yarıda bırakıldığı ya da anket bütünlüğünü bozacak şekilde cevaplandırılmamış sorular bulunduğu tespit edilmiştir. Bu durum çalışmanın güvenirliğini ve geçerliliğini etkilememesi açısından dikkatle incelenmiş ve sadece tam cevaplandırılmış anketler değerlendirmeye alınmıştır.

Ankette yer alan sorulara katılımcıların " 0 " fikrim yok, "1" hiç katılmıyorum ve "5" tamamen katıllyorum arasında puan vermeleri istenmiştir. Bu puanlar ile katılımcılar açısından her grupta yer alan soruların genel ortalamaları belirlenmiştir. Ayrıca ankete katılan akademisyenlerin aynı soruları a)şu anda çalıştıkları üniversite, b)Türkiye genelinde uygulaması c)akademisyenlik mesleğindeki önemi açısından değerlendirmeleri istenmiştir. Bu değerlendirme sonucunda "3.97” ortalama ile akademisyenlik mesleğinde önemi seçeneği ilk sırada yer alırken, şu anda görev yaptıkları üniversite için " 2.86 ", Türkiye genelinde ise "2.24" ortalama elde edilmiştir. Bu oran genel olarak etik kodların tüm katılımcılar tarafından akademisyenlik mesleği açısından önemsendiğini ancak çalıştıkları üniversite ve Türkiye'deki üniversiteler açısından etik kodların gereği gibi uygulanmadıklarını düşündükleri anlaşılmaktadır. Ayrıca bu ortalama çalışmamızda yer verdiğimiz Tedmer in 2006 yllına ilişkin yapmış olduğu ve Nisan 2007 de açıkladığı Türkiye etik göstergeler araştırmasının sonuçları ile de benzerlik taşımaktadır (Tedmer, 2007).

Ankete katılan akademisyenlerin cinsiyete göre dağılımına bakıldığında \%48.8 kadın, \%51.2 erkek katılımcı ile dengeli bir dağılım olduğu gözlenmiştir. Ankete katılanların \%94.2 ${ }^{\text {ee }}$ devlet üniversitesinde görev yapmaktadır. Anket sonucunda devlet üniversitesinde görev yapan 
akademisyenlerin etik ilkelerin akademisyenlik mesleğindeki önemi açısından, vakıf ve özel üniversitelerde görev yapan akademisyenlere göre daha yüksek oranda önem verdiği gözlenmiştir. Bilime karşı sorumlulukların akademisyenlik mesleğindeki önemini belirlemeye yönelik sorularda devlet üniversiteleri " 4.16 " ortalamaya sahipken, vakıf üniversitelerinde bu ifadenin ortalaması “1.73” olarak karşımıza çıkmaktadır. Akademik unvanlara göre bakıldığında ise, ankete katılanların \%37.21 si araştırma görevlisidir. Araştırma görevlileri Türkiye genelinde üniversitelerde uygulanması açısından yaptıkları değerlendirmede, özellikle mesleğe ve meslektaşa karşı gruplarında yer alan sorulara "1.93” ve "1.90” gibi düşük ortalamalar vermişlerdir. Yani, mesleğin ilk basamağında sayılan akademisyenlerin, meslek ve meslektaşa karşı sorumluluk açısından etik dışı eylemler gözlemlediğini ortaya koymaktadır. Bu durum da çalışmanın çıkış amacını desteklemektedir. Faaliyet alanları incelendiğinde ise sosyal bilimlerden \%64.5lik bir katılım sağlanmıştır. Ancak faaliyet alanlarına göre soruların cevaplanmasında istatistiksel açıdan anlamlı bir farklılık gözlenmemiştir. Bu durum etik değerlerin branşlara göre farklılık göstermediğini, her tür faaliyet alanında benzer ortalamaya sahip olduğunu ortaya koymuştur.

Akademisyenlik mesleğindeki etik kodları belirlemek amaçlı verilen ifadeler; bir akademisyenin etik açıdan sorumluluk duyması gereken alanlar dikkate alınarak, a) öğrenciye, b)meslektaşa, c) mesleğe, d) topluma ve e) bilime karşı olmak üzere toplam beş grupta değerlendirilmiştir. Söz konusu gruplar, konuyla ilgili literatürde yapılan açılama ve tanımlamalardan yararlanılarak, bu ve benzeri alanlarda çalışan akademisyenlerin görüş ve önerileri doğrultusunda tarafımızca hazırlanmıştır. Gruplama soruların hazırlanışı aşamasında akademisyenlerin, mesleklerinin gereği olarak sorumlu oldukları çevreler gözetilerek yapılmıştır.

\section{Etik Kodların Öğrenciye Karşı Sorumluluklar Açısından İncelenmesi}

Ankette yer alan etik ilkelerin gruplandırılması sonucunda, öğrenciye karşı sorumlulukla ilgili ifadeler belirlenmiştir. Söz konusu ifadelere katılımcılar tarafından, i) Türkiye genelinde uygulanması ve ii) Akademisyenlik mesleğinde olması istenilen açısından verilen puanların aritmetik ortalamalarıyla Şekil:1 oluşturulmuştur. 


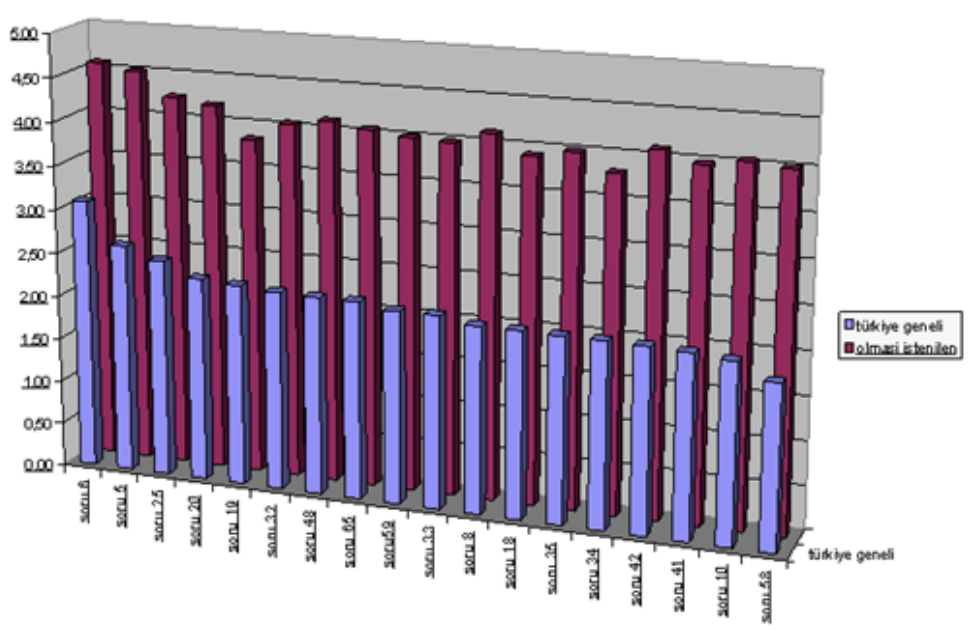

Genel olarak ortalamalar arasında önemli farklar olduğu, şekil 1 de görülmektedir. Bu farklılık bize akademisyenlerin öğrenciye karşı sorumlulukları açısından her anlamda özenli ve dikkatli olmaları konusunda genel bir kabulün olduğunu ortaya koymaktadır. Ancak bu genel kabulün uygulama aşamasında yeterince etkin uygulanamadığı şekil 1'de açık şekilde gözlenmektedir. Akademisyenlik mesleğinde olması istenilen seçeneğine verilen puanlar 3,75 ve üzeri olarak belirlenmiştir. Öte yandan Türkiye genelinde uygulanılan seçeneğine verilen puanlar 1,75 ve 3 puan arasındadır. Bu iki seçeneğe verilen cevaplara göre yüksek fark olan bazı sorular aşağıda sıralanmaktadır.

Soru 58: "Akademisyenler, siyasal görüş benzerliği, akrabalık, hemşerilik gibi nedenlerden dolayı belirli öğrencilere imtiyazlı davranmazlar."

Soru 10: "Akademisyenler, öğrencilerine kendi çalısmaları ile ilgili ödev hazırlatarak, bunlardan faydalanmazlar ve faydalanmayı düşünmezler."

Soru 8: "Akademisyenler, derse asistanı göndermeyi alıskanlık haline getirmezler."

Soru 42: "Akademisyenler, derslerine, konuları güncelleyerek, yenilikleri takip ederek, vs. gerekli özeni gösterirler."

Soru 41: "Akademisyenler, kişisel yakınlık ile öğrenci - öğretmen ilişkisini birbirine karıştırmazlar."

Soru 5: “Akademisyenler, öğrencileri küçük düşürücü veya hakaret edici davranışlarda veya eylemlerde bulunmazlar."

Soru 35: "Akademisyenler, çalışma arkadaşlarını öğrenciye çekiştirmezler."

Yukarıda belirtilen soruların genel olarak öğrencinin kişiliğine, inançlarına, değer yargılarına, emeğine sayg1 duyan akademisyenler ile bir arada olmaları gerektiğinin ‘ideal olan’ olarak değerlendirildiği soruların aldığı yüksek puan ortalamaları ile ortaya konulmaktadır. Öte yandan Türkiye genelinde üniversitelerin pek çoğunda öğrenciye karşı sorumlulukların gereğince yerine getirilmediğini düşünmektedirler. İdeal olan açısından tam puana yakın oranlar verilirken uygulama acısından ortalama bir puanlama ile değerlendirildiği şekil 1'de gözlenmektedir. 


\section{Etik Kodların Meslektaşa Karşı Sorumluluk Açısından İncelenmesi}

Ankette yer alan etik ilkelerin gruplandırılması sonucunda, akademisyenlik mesleğinde meslektaşa karşı sorumlulukla ilgili ifadeler belirlenmiştir. Bu ifadelere katılımcılar tarafindan, i) Türkiye genelinde uygulanması ve ii) Akademisyenlik mesleğindeki olması istenilen açısından, verilen puanların aritmetik ortalamalarıla şekil 2 oluşturulmuştur.

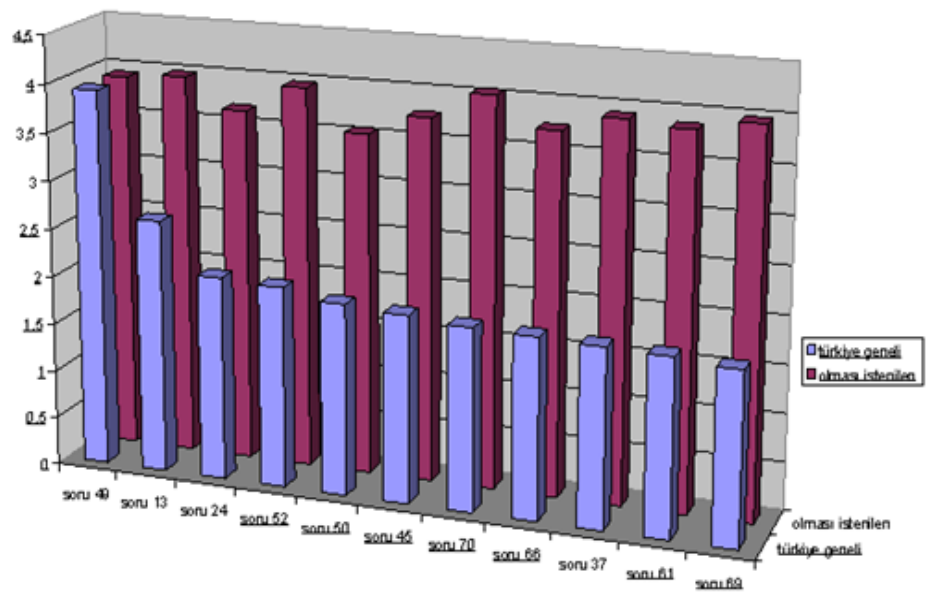

Meslektaşa karşı sorumluluklar incelendiğinde, soru 49: "Akademisyenler, şahsi işlerini gerek astlarına gerekse diğer görevlilere gördürmezler" ifadesi her iki değerlendirmede de başa baş değere sahip olmakla birlikte diğer ifadelerde önemli farklar dikkat çekmektedir. Bu ifadelerden ideal olan seçeneğine verilen ortalama puan ile Türkiye genelinde uygulanılan seçeneğine verilen puan arasında yüksek fark olan bazı sorular aşağıda sıralanmaktadır.

Soru 69: Akademisyenler, kurum içinde çalışma arkadaşlarını veya kurumu etkileyecek davranışlarda (dedikodu vs.) bulunmazlar.

Soru 70: Akademisyenler, astlarının performans değerlendirmesinde, her türlü (önyarg1, benzerlik, zıtlık, vs.) sübjektif kriterlerden kaçınarak, tamamen adil ve objektif olarak bilimsel liyakate dayalı kriterlerle hareket ederler.

Soru 37: Akademisyenler, astları arasında iş bölümünde adil davranırlar.

Soru 61: Akademisyenler, ast - üst konumundaki hiçbir meslektaşına asla yalan söylemezler.

Soru 52: Akademisyenler, bilim için elde ettikleri bilgiyi meslektaşları ile paylaşırlar.

Akademisyenlik mesleği doğası gereği iş birliği ve ortak çalışma kavramlarını akla getirmektedir. Öyle ki dünya genelinde yapılan pek çok akademik çalışma iki ve daha fazla yazarı bünyesinde barındırmaktadır. Bu durum akademisyenlerin meslektaşları ile biraradalığını göstermektedir. Yukarıda belirtilen tüm sorularda da akademisyenlik mesleğinde etik değerlerin bir arada çalışma ortamının oluşması anlamında oldukça önemli olduğunu gösterirken, diğer yandan Türkiye 
genelinde uygulamasına baktığımızda etik değerlerin yeterince uygulanmadığının düşünüldüğü açık şekilde görülmektedir.

\section{Etik Kodların Mesleğe Karşı Sorumluluk Açısından İncelenmesi}

Etik kodlanın mesleğe karşı sorumluluk açısından incelenmesinde hem ülkemiz yüksek öğretim kurumlarında uygulanması hem de akademisyenlik mesleği açısından olması istenilen dikkate alınarak verilen puanların ortalamaları şekil 3'de görülmektedir.

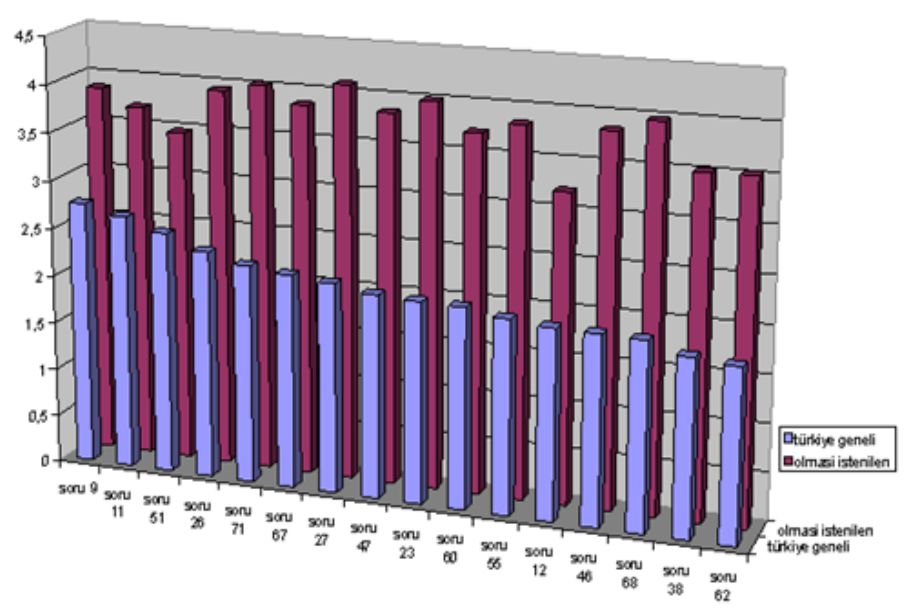

Akademisyenlik mesleğinde olması istenilen açısından bütün sorularda dikkat çekici farklar olmasına karşın en yüksek fark gözlenen sorulara bakıldığında kişisel menfaatlerin akademisyenlik mesleğinin önünde tutulması halinin katılımcılar arasında yaygın şekilde belirtildiği gözlenmektedir. Aşağıda yer alan bazı sorular bu durumu ortaya koymaktadır.

Soru 68: Akademisyenler, her ne amaç için olursa olsun kurum içinde siyasi amaçla hareket etmezler.

Soru 27: Akademisyenler derslerinde, maddi çıkar sağlamak için belirli kitap, doküman, vs. talep etmezler.

Soru 23: Akademisyenler, kuruma ait doküman, kaynak ve araçları kasıtlı olarak uzun süre mülkiyetlerinde bulundurmazlar.

Soru 46: Akademisyenler, ders dokümanlarını pazarlama yoluyla kazanç elde etmezler.

Soru 55: Akademisyenler, kurumun düzenlediği toplantılara mazeretsiz olarak katılmamay1 alıskanlık haline getirmezler.

Ankete katılan akademisyenlerin genel olarak mesleğe karşı yüksek değer yargıları besledikleri ve sayg1 duydukları şekil 3'de açık şekilde görülmektedir. Ancak Türkiye genelinde uygulanması açısından akademisyenler bazı meslektaşlarının kişisel çıkarlarını maddi manevi her anlamda 
mesleki değerlerden önde tutuklarını belirtmektedirler. Bu durum ankete verdikleri cevaplar ile açık şekilde gözlenmektedir.

\section{Etik Kodların Topluma Karşı Sorumluluk Açısından İncelenmesi}

Etik kodların akademisyenlik mesleğinin topluma karşı sorumluluk açısından belirlenmesinde sorulan sorulara verilen puanların ortalamasıyla şekil 4 oluşturulmuştur.

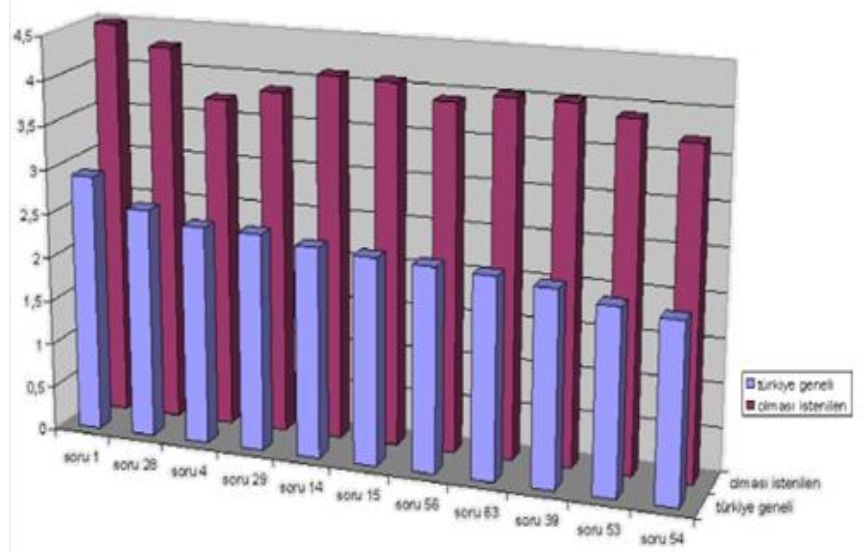

Akademisyenlik mesleği toplumsal anlamda belirli roller taşımaktadır. Akademisyenler genç zihinleri yetiştirerek, onlara örnek olmaktadır. Bu anlamda akademisyenlerin topluma karşı bazı sorumlulukları vardır. Çalışmanın bu bölümünde akademisyenlik mesleğinde etik kodların topluma karşı sorumluluk açısından meslekteki önemi ve Türkiye genelinde uygulanması arasında ortalamaları kıyaslandığında önemli fark olan bazı sorular aşağıda sıralanmaktadır.

Soru 39: Akademisyenler, iyi eğitilmiş, genç bilim insanlarını topluma kazandırıllar.

Soru 53: Akademisyenler, eğitim faaliyetlerini sınıf ile sınırlandırmayarak, her zaman yol gösterici olurlar.

Soru 63: Akademisyenler, mesleki uzmanlık ve üstünlüğü hiçbir zaman insanları aşağılamak, kandırmak için kullanmazlar.

Soru 15: Akademisyenler, yapacakları araştırmalarda insanlık yararını ön planda tutarlar.

Soru 14: Akademisyenler, bilimsel çalışmaların sonuçları konusunda toplumu zamanında ve doğru bilgilendirirler.

Şekil 4 incelendiğinde akademisyenlerin bazı meslektaşlarını topluma karşı yol gösterici olma, bilgilendirme, insanlı yararını ön planda tutma gibi bazı temel değerler noktasında yeterli bulmadıkları görülmektedir. 


\section{Etik Kodların Bilime Karşı Sorumluluklar Açısından İncelenmesi}

Akademisyenlik bilim temelinden yola çıkan ve ilim, irfan için hizmet vermeye çalışan bir meslek dalıdır. Bu sebeple bilime karşı akademisyenlerin sorumlulukları vardır. Etik kodların bilime karşı sorumluluk açısından incelenmesinde elde edilen sonuçlar şekil 5'de görülmektedir.

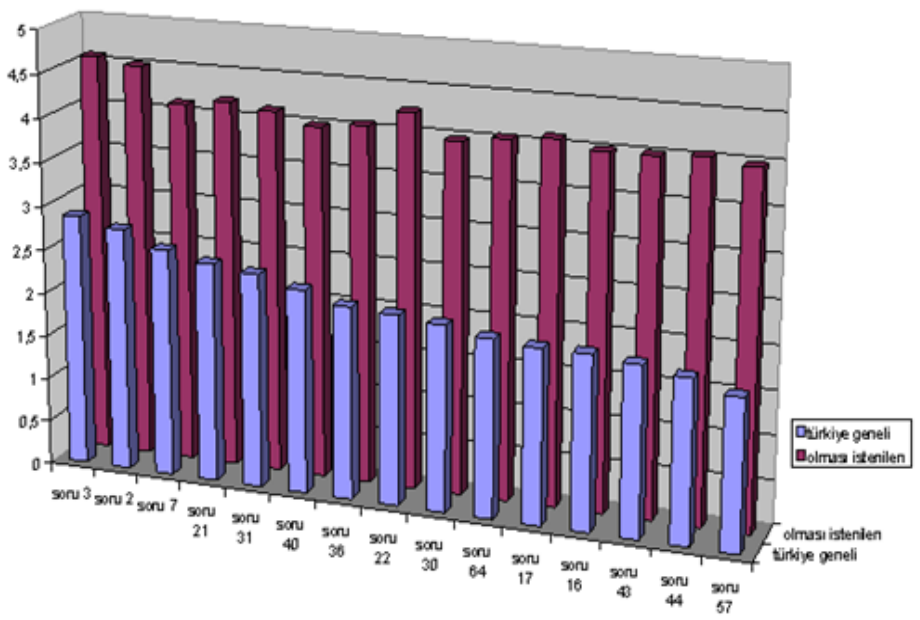

Ortalamalar arasında önemli fark olan ifadelere bakıldığında ise;

Soru 57: Akademisyenler, ikram yazarllğından (çalışmaya herhangi bir desteği bulunmadı̆̆1 halde çalışmada isminin yer alması) kaçınırlar.

Soru 44: Akademisyenler, akademik yükseltme sınavlarında sadece bilimsel liyakate dayalı olarak hareket ederler.

Soru 17: Akademisyenler, maddi destek sağlanan çalışmalarında destek sağlayanlara karşı tarafsizdırlar.

Soru 22: Akademisyenler, genç bilim insanlarına önderlik yaparlar.

Soru 43: Akademisyenler, bilimsel çalş̧malardan sağlanan parasal desteği uygunsuz bir biçimde (bilim dışı amaçlarla) kullanmazlar.

Soru 16: Akademisyenler, tek bir çalışmadan çıkan sonuçları yapay bir şekilde bölerek birden fazla yayında yayınlamazlar.

Soru 64: Akademisyenler, akademik hayatın her aşamasında "bilimsel liyakat" kriterini temel alırlar.

Diğer bütün alanlarda değindiğimiz gibi bilim alanında da akademisyenlerin olması istenilen ve Türkiye genelinde olan açısından sorularımızı puanladıklarında beliren geniş aralık açık şekilde bilimin hak ettiği düşünülen değeri akademisyenlerden göremediğini göstermektedir. Bu durum bilim için mesleğe adım atan tüm diğer meslek çalışanları için oldukça üzücüdür. 
Akademisyenlerin bilimsel liyakata önem veren, genç bilim insanlarına önderlik yapan bireyler olması gerektiği ancak bu durumun uygulamada yeterince gözlemlenemediği belirtilmektedir.

\section{Sonuç}

Çalışma kapsamında, uygulanan ankette yer alan akademisyenlik mesleğinde etik kodların belirlenmesine yönelik ifadelere verilen puanlar incelenmiştir. İnceleme sonucunda her grup için, ankette yer alan, etik ilkelerin akademisyenlik mesleğinde önemi açısından, en yüksek aritmetik ortalamaya sahip ifadelerden yola çıkarak 'akademisyenlik mesleğindeki etik kodlar' geliştirilebileceği düşünülmüştür. Katılımcıların belirttiği görüşlere göre akademisyenlik mesleğiyle ilgili olması önerilen etik kodları beş başlık altında toplamak etik kodların hangi açıdan ele alınacağını daha net ortaya koyması anlamında önemlidir. Bu noktadan hareketle öğrenciye, meslektaşa, mesleğe, topluma ve bilime karşı sorumluluk açısından belirlemeye çalışılan etik kodlara bakıldığında;

Akademisyenlik mesleği öğrenciler ile biraradalığ1 gerektirir. Bu sebeple akademisyenlerin öğrencilere karşı etik değerler dahilinde olan tavırları her koşulda en önemli gerekliliklerdendir. Akademisyenin her bir öğrenciye tutarlı ve eşit davranması mutlaktır. Çalışma dahilinde ön görülen öğrenciye karşı sorumluk açısından etik kodlar şu şekildedir; Akademisyenlerin sınav kağıtlarını okumadan, okunmuş gibi göstermemeleri ve öğrencilerinin başarılarını değerlendirirken tamamen rasyonel davranmaları gerekmektedir. Öğrencilerin başarılarını değerlendirirken, hiçbir etki altında olmadan ve dikkatli, özverili bir şekilde davranılması hedeflenmektedir. Başarısının, emeğinin karşılığını alan bir öğrencinin hem eğitim hayatında hem de sosyal hayatta daha başarılı olacağı düşünülmektedir. Bunun yanı sıra bağımsız ve özgüveni yüksek bireyler yetiştirmeyi amaçlayan akademisyenlerin, öğrencileri küçük düşürücü veya hakaret edici davranışlarda veya eylemlerde bulunmamaları, her ne koşulda olursa olsun cinsel tacize asla izin vermemeleri gerekmektedir. Ayrıca akademisyenlerin öğrenci ile etkileşimini sağlayan ve bu bağı güçlendirmede etkin role sahip akademisyenin vermekle yükümlü olduğu derslere asistanı göndermeyi alışkanlık haline getirmemeleri gerektiği düşünülmektedir.

Akademisyenler sürekli gelişen bilim dünyasında ancak birbirleri ile iletişim sayesinde bu değişime ayak uydurma şansına sahiptir. Birbirlerini akademik anlamda beslerler ve üretim süreçlerine katkı sağlarlar. Akademisyenlik mesleğinde meslektaşlara karşı sorumlulukla ilgili etik kodlar, bu iletişimin sağlıklı bir şekilde sağlanması ve daha etkin üretim süreçlerinin oluşması için önemlidir. Bu sebeple, akademisyenler, gerek üst- ast gerekse aynı düzeydeki meslektaşlarıyla gerekli zamanlarda, gerekli ilişkileri kurmaktan kaçınmazlar ve bilim için elde ettikleri bilgiyi 
meslektaşları ile her zaman paylaşırlar. Ayrıca akademisyenler, astlarının performansının değerlendirilmesinde, tamamen adil ve objektif olarak bilimsel liyakate dayalı kriterlerle hareket etmelidir, kurum içinde çalışma arkadaşlarını veya kurumu etkileyecek davranışlarda (dedikodu vs.) bulunmamalıdır ve şahsi işlerini gerek astlarına gerekse diğer görevlilere gördürmemelidir.

Akademisyenlik mesleğinde, mesleğe karşı sorumluluklarla ilgili etik kodlar, eğitimin ve bilimin gelişmesi ve saygınlığını koruması için gereklidir. Bu sebeple akademisyenler mesleğin gereklerine uygun davranmaları önemlidir. Öyle ki akademisyenler, “Öğrencinin kapasitesi yeterli değil.”, “aldığımız maaş düşük” gibi veya "başka akademisyenlerde böyle yapıyor" diye hareket etmezler. Ayrıca derslerinde, maddi çıkar sağlamak için belirli kitap, doküman, vs. talep etmezler ve derslerini fiilen yaparlar. Akademisyenler, kuruma ait doküman, kaynak ve araçları kasıtlı olarak uzun süre mülkiyetlerinde bulundurmazlar ve kuruma ilişkin gizli nitelikteki bilgilerin dişarıya sızdırılmaması için azami özen ve dikkati gösterirler. Akademisyenlik mesleğinde tarafsılılı önemli bir kavramdır ve etik kodlar arasında yer alan, her ne amaç için olursa olsun kurum içinde siyasi amaçla hareket etmezler. Akademisyenler mesleğe karşı etik değerler doğrultusunda davrandıkça mesleğin önemi de artmaktadır.

Üniversiteler toplumu ve tüm insanlığı, ekonomi, sağlık, politika gibi pek çok konuda aydınlatmakla ve yaşanılan sorunlara çözüm üretmekle sorumludur. Akademisyenlik mesleğine yönelik etik kodları belirlerken bu sorumluluk gözetilmiştir. Bu nedenle akademisyenler, yalnızca bilim çevresinin değil, toplumun da güven ve saygısını kazanmaya özen gösterirler. Ayrıca akademisyenlerin, toplumu "bilim" konusunda doğru bir şekilde bilgilendirmeleri, bilimsel çalışmaların sonuçları konusunda toplumu zamanında haberdar etmeleri ve yapacakları araştırmalarda insanlık yararını ön planda tutmaları gerektiği belirtilmektedir. Akademisyenlerin topluma karşı bir diğer sorumluluğu da iyi eğitilmiş, genç bilim insanlarını topluma kazandırmalarıdır.

Akademisyenlik mesleğinde bilime karşı sorumlulukları belirten etik kodlarda ise akademisyenlerin, daha önce yayınlanmış bir yayının tümünü ya da belli bir kısmını kaynak göstermeksizin, kendi yayını gibi yeniden yayınlamamaları, gerçekte var olmayan verileri ve sonuçları çalışmalarında kullanmamaları ve akademisyenlerin konularında bilimsel açıdan yetkin olması gerektiği belirtilmiştir. Ayrıca bilim dünyasındaki değişimleri takip etmek için akademisyenlerin, meslektaşlarıyla iş birliğine girmekten kaçınmamaları gerekmekte ve bilimdeki bu gelişmelerin devamlılığını sağlamak adına genç bilim insanlarına önderlik yapmaları gerekmektedir. 
Bu çalışma kapsamında anket verilerinin incelenmesi ile elde edilen sonuçlar akademisyenlik mesleğinde etik kodların gerekli olduğunu ortaya çıkarmıştır. Ankette yer alan ifadeler olması istenilen açısından aldıkları yüksek puanlar ile etik konusunun akademik olarak taşıdığı değeri göstermektedir. Uygulanılan ankette yer alan 71 ifade ile akademisyenlik mesleğinde etik anlamda nelerin önemli olduğu belirlenmeye çalışılmış ve yüksek ortalamaya sahip olması sebebiyle ankette katılan akademisyenler tarafindan önemli olduğu vurgulanan ifadeler bir araya toplanmıştır. $\mathrm{Bu}$ ifadelerin akademisyenlik mesleğinde etik kodların geliştirilmesi çalışmaları için yol gösterici olacağı düşünülmektedir.

\section{Kaynakça}

Atayman, V. (2005). Etik, İstanbul: Donkişot Yayınları.

Baumhart, R. (1968). Ethics in Business, New York: Holt, Rinehart and Winston.

Harlak, H. (2003). Temel İletişim Becerileri, Aydın: ADÜ Yayınları.

Johnson, A. O. ve Reath, A. (2004). Ethics: Selection From Classic and Contemprary Writers, C.A.: Wadsworth.

Kant, I. (2003). Ethica, Etik Üz̧rine Dersler, (Çev: Oğuz Özügül), İstanbul: Pencere Yayınları.

Kuçuradi, İ. (2006). Etik, Ankara: Türkiye Felsefe Kurumu.

Kuçuradi, İ. (2003). Etik ve Etikler, Türkiye Mühendislik Haberleri Dergisi, Say1 423 2003/1,7-11.

Ortaş, İ. (2004). Öğretim Üyesi ya da Bilim Adamı Kimdir?. Pivolka: Bașkent Üniversitesi EleștirelYaratıc Düșünme ve Davranıs Araștırmalar Laboratuvarlan Dergisi, 3:12, s.11-16.

Pater, A. ve Gils, A. V. (2003). Stimulating Ethical Decision- Making in a Business Context: Effects of Ethical and Professional Codes. European Management Journal, 21: 6.

Preston, N. (1996). Understanding Ethichs, Sidney: Federation Press.

Russ- Eft, D., ve Hatcher, T. (2003). The Issues of International Value and Believes: The Debate For A Global Hard Code of Ethics. Advances in Developing Human Resources, 5:3, s.304.

Svensson, G., Wood, G. (2004). Codes of Ethics Best Practice in The Swedish Public Sector: A Pubsec - Scale. The International Journal of Public Sector Management, 17:2, s.180.

TEDMER, (2007). http://www.tedmer.org.tr/pps/etikbarometre.pps erişim tarihi 23.05.2007 
Tepe, H. (1992). Etik ve Meta-etik: 20. yy. Etiğinde Normatiflik Tartısması, Ankara: Türkiye Felsefe Kurumu.

Tevruz, S. (2007). Etik Yakılaşımlar ve İs Ablakı, İs Hayatında Etik, İstanbul: Beta Yayınları.

Yllmaz, G. (2007). Akademisyenlik Mesleğine Yönelik Etik Kodlarn Geliştirilmesine Illişkin Görgül Bir Araştırma. Yayınlanmamış Yüksek Lisans Tezi, Manisa Celal Bayar Üniversitesi Sosyal Bilimler Enstitüsü İşletme Anabilim Dalı Yönetim ve Organizasyon Programı. 